\title{
The Knowledge Society and Diversification of Higher Education: From the Social Contract to the Mission of Universities
}

\author{
Attila Pausits
}

\section{Introduction}

The European higher education policy has nowadays been dominated by an ambitious modernization of nation-state higher education systems. These reform processes have significantly influenced both core missions of higher education institutions (HEIs), namely research and teaching. The university's autonomy and governance, the Bologna Process, the Excellence Initiative, but also the changes in the funding of higher education (HE) - to mention some of the key issues - have led to a fundamental discussion on the role and responsibilities of HEIs (Altbach and Peterson 2007; D’Ambrosio and Ehrenberg 2007; Huisman and Pausits 2010). The changes range from comprehensive system reforms to institutional change processes, which are often expressed and propagated with headings like "from government to governance" (Bergan et al. 2011), "from teaching to learning" (Nygaard and Holtham 2008) or "from research to innovation" (Etzkowitz and Leydesdorff 2000). There are examples of a necessary change and a new alignment of the social contract (Daxner 2010) for HEIs, e.g. new financing models; trends such as the expansion of tertiary education; or the right of active participation in the process of lifelong learning (Davies et al. 2010).

But these new developments and changes lead to the same question: alongside teaching and research are there other tasks for a modern university in a knowledge society? If so, then the existing social contract between HEIs and society has to be renegotiated. Politicians, decision-makers and university administrators are in search for a new identity and a new strategic anchoring of the modern university in society (Kerr 2001; Molas-Gallart et al. 2002). In this process, they are repeatedly using the so-called 'third mission' (Etzkowitz and Leydesdorff 1997; Mahrl and

\footnotetext{
A. Pausits $(\bowtie)$

Danube University Krems, Krems an der Donau, Austria

e-mail: attila.pausits@donau-uni.ac.at

(C) The Author(s) 2015

A. Curaj et al. (eds.), The European Higher Education Area,

DOI 10.1007/978-3-319-20877-0_18
} 
Pausits 2011) as a synonym for a modern university: a subject that has caused a variety of publications (Arbo and Benneworth 2007) and a series of meetings and conferences worldwide. ${ }^{1}$ It often involves tasks not covered entirely through the first two traditional core functions of universities: teaching and research. The reaction, universities already have enough to do, and therefore do not need yet another 'mission', disappears in the media discussion of the renewal of the international and European higher education landscape. Both the policy and the universities themselves recognize a social, as well as, institutional need for (re) opening. The third mission becomes more and more the vehicle to leave the "ivory tower" (Mahrl and Pausits 2011).

The first step of this opening means to understand the university's institutional role. Even if by the term university we do mean a special form of organization, which is linked to operate with the specific mission in teaching and research, there are many different forms of implementation: the research-intensive, the regional, the teaching-oriented, universities for further education, both private and public universities, virtual, technical, applied sciences etc. (van Vught 2009). This variety makes comparisons difficult, and a classification is needed. Thus, differences can be uncovered, but sometimes also developed and protected. The U-Map project ${ }^{2}$ funded by the European Union, delivered the first feasibility study on a European framework, similar to the Carnegie classification ${ }^{3}$ and the Russell Group. ${ }^{4}$ This comparison is inevitable, on one hand because of increasing competition and scarce resources, but on the other hand also for institutional profile-building, to provide differentiation among each other. It becomes evident, underlined through the development of the European Standards and Guidelines for Quality Assurance in Higher Education by ENQA (the European Association for Quality Assurance in Higher Education), and also within the systemic and institutional upgrading of quality assurance and development. These Standards are the common working measures and foundation of quality assurance agencies in Europe.

New mega-national quality assurance agencies are established these days to be able to fulfil their tasks and to be competitive on an international quality assurance marketplace, e.g. in Austria and Finland. Furthermore, the former national agencies are operating more internationally. For example, the Karl-Franzens-University in Graz has been evaluated by the Finnish accreditation agency, FINHEEC. From this example, it is again clear that international comparisons and benchmarks are not only generated by initiatives such as U-Map, but also by supranational quality assurance mechanisms. Therefore, for the review of institutional quality measures, international standards and quality requirements are to be used, and thus provide support for the institutional profile-building (Pichl 2012) in a global competition.

\footnotetext{
${ }^{1}$ See http://e3mproject.eu/final-conference-note.html; http://www.mohe.gov.sa/en/news/Pages/ news-1-4-1434.aspx.

${ }^{2}$ See www.u-map.eu.

${ }^{3}$ See http://classifications.carnegiefoundation.org/.

${ }^{4}$ See http://www.russellgroup.ac.uk/.
} 
Standards and profiling are two elements of the current academic discussion that highlight not only the width, but also the depth of a particular complexity of knowledge production and interaction. The tasks of rectors are to develop an institutional profile of their universities, to identify and use external funding, to develop more efficient and effective organisations, and to sustain academic excellence with strategic advantages. In this context of a modern, entrepreneurial, and progressive university, we refer repeatedly to the third mission as a catalyst and barometer (Arbo and Benneworth 2007; Etzkowitz 2008; Molas-Gallart et al. 2002). It is assumed, that from the development of the third mission, the other two core areas of the university benefit as well (Mahrl and Pausits 2011). Up to now, there are no empirical studies on this theory. Does the third mission lead to the desired overall development and the contemporary university as an organization? Can such a mission and profile be used for further diversification? Or is it just another slogan on crisis-ridden skies of HE?

The following article deals with this phenomenon and attempts to develop a theoretical and conceptual framework of this third pillar of university activities. First, an overview of the relevant literature is presented, followed by concepts for describing the different dimensions and tasks subsumed under the term third mission. These concepts will help not only to get an overview of this area, but also to understand the challenges and limitations of the term third mission, as well as deliver indicators to measure third mission activities. Today, many rankings use different indicators to value the 'quality of universities'. In this article rankings will be taken as a point of reference, to evaluate them based on their focus areas. The key question is how many aspects and measures have been used so far to 'rank' universities based on their performance and quality profile? If we follow the international discussion about the changes in HE, then the rankings should also adapt their indicators based on the social contract (Mahrl and Pausits 2011; Montesinos et al. 2008). Therefore, the empirical part of this paper will analyse the indicators and group them related to the missions of universities, in order to see how far rankings reflect the third mission and the diversification of higher education.

\section{Institutional Approach and Contextualization: Previous Research Findings}

The importance of universities is based on their achievements in research and teaching, and not on their willingness to make institutional changes (Shattock 2003). Nevertheless, these same changes are necessary to develop these two core missions and to create the modern university environment. Standardization in research and teaching can be established by quality assurance and development (Brennan and Shah 2000). These standardization tools enhance unification of services and processes, and thus produce minimum standards. Additionally, this means a change in the basic expectations of the stakeholders towards the universities. The university as a "Community of Scholars" is becoming the "Community of Practice" 
(Barnett 2003; Maassen and Olsen 2007). This is a new understanding of quality, which is supported by the development of indicators, standardized processes, audits and peer reviews, and implemented through professional university management. It means a shift in the institutional focus from an academic oligarchy to organization and markets (Clark 1983). The concept of the university described by Weick as a "loosely coupled system" (Weick 1976) has been transformed into new concepts. One of these concepts is aimed at extending the responsibilities of the university as a transformative characteristic (Barnett 2003; Kerr 2001).

The term 'mission' is derived from the Latin word missio (broadcast) and described at the beginning only by the extension of faith. The third mission of the university, however, has more to do with the organizational theory meaning of the term: a mission as a mandate (Altbach and Peterson 2007). In the literature, the third mission is derived from two different perspectives. One perspective focuses on the tasks of a university and subscribes the need to define another mission from the complexity of the tasks (Cross and Pickering 2008; Daxner 2010; Goddard and Puukka 2008; Mahrl and Pausits 2011). The other perspective justifies the third mission through the university as a special organizational form and the associated social role (Molas-Gallart et al. 2002; Montesinos et al. 2008).

Already in the 70s, the German Education Council defined Continuing Education as the third pillar of universities (Deutscher 1975). This aspect was enhanced, not in the least, due to the current debate about the importance of lifelong learning (LLL) and the role of universities in this context. Logical consequences are the development of LLL strategies in all Austrian universities, the establishment of continuing education centres within or outside the universities, and also in establishment of national or international networks for continuing education. It is clear that in addition to education, continuing education advances to core functions of universities. Universities advance from a "partner to teach" in certain stages of life, to a "partner to learn" for a lifetime (Davies et al. 2010).

Another approach to the third mission, from the perspective of tasks, can be made through research and the production of knowledge. In their publication Gibbons et al. (1994) describe the need for greater contextualization of the research, as well as an opening in the direction of the markets, and also the society and other stakeholders, as an integral part of knowledge creation. This means that the relevance of the research increasingly depends upon the customers and stakeholders. The authors refer to this as "Mode 2" and point out a progressive importance of science for and in the society. The new model should move away from hierarchical and discipline-oriented research towards more interdisciplinary and application-oriented research. This describes a widened understanding of research as a second mission of universities. At the end, both teaching and research are confronted with a change in their understanding and organizational purpose.

In teaching, these changes resulted in reform in the structure (the Bologna Process), and in the emphasis and expansion of postgraduate education at universities. However, in research, a number of new concepts (Edquist 1997; Etzkowitz and Leydesdorff 2000) on the role of universities in national innovation systems have been developed. This includes the concept of the Triple Helix (Etzkowitz and 
Leydesdorff 1997). They describe the relationship between university, industry and the public sector, and thereby define, in addition to research and teaching, knowledge transfer to society as a further-third — task.

Both changes in teaching and in research indicate an institutional adjustment and modification of the original tasks, or at least an extension of those. In the development of such concepts, the "Entrepreneurial University" described by Burton Clark plays a significant role. The entrepreneurial university takes responsibility for its core tasks and yet, remains flexible and able to adapt adequately to social developments. Obviously, there is not one single approach to the entrepreneurial university (Clark 1998). There are rather multiple examples of good implementation in the national higher education contexts applying to the definition by Burton Clark. It is not about the use of a schematic model of the entrepreneurial university, but rather to find institutional and individual responses for a new type of university.

The modernization agenda of universities has many different aspects, however apparently all come together in this "new" third mission. Governments are demanding more accountability from the universities and more responsibility for the funds provided to them. New concepts of universities, such as the University Alto, an integration of three different universities in Finland into single one, or the Danube University Krems in Austria, the only public university for continuing education in Europe, are examples for a new differentiation of higher education. The quest for "World Class University" and elite positions in international university rankings as a measure of achievement on the one hand, and universities with a strong regional focus on the other hand, are two of many differentiations in a new global, national and regional competition for resources (Arbo and Benneworth 2007; Barnett 2003; van Vught 2009). The university will be increasingly characterized by institutional diversity in the future (Clark 2004; Shattock 2003).

Surprisingly, a comprehensive discussion on the third mission at the universities does not take place yet. It is rather dominated by topics viewed by involved actors as more important, such as funding and access to higher education. Both the involvement of stakeholder groups, as well as the gain of an understanding of all stakeholders on the meaning, form and interactions of the tasks in this context, is necessary. Common understanding about the goals of the third mission is needed to enhance further developments in this field. Therefore some of the key concepts are presented in following chapter.

\section{The Taxonomy of the Third Mission}

\subsection{The Russell Group}

The Russell Group, an association of leading research-intensive universities in the UK, had already installed a working group for the development of a concept for the third mission in 2002. The working group noted that universities have always provided a contribution to decision-making processes for wide society-related 


\section{Associated Third Stream activities}

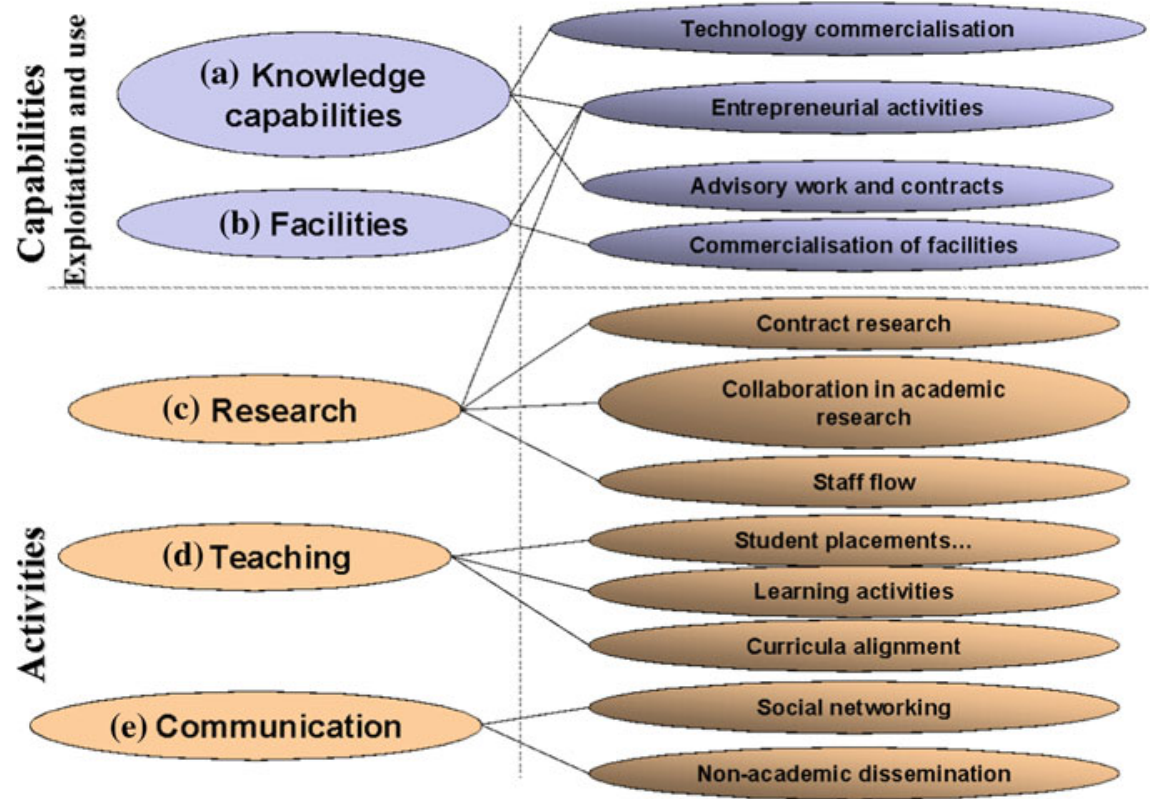

Fig. 1 Conceptual reference framework for the analysis of activities of the third mission (Molas-Gallart et al. 2002)

topics. Therefore, the third mission was defined as "the generation, use, application and exploitation of knowledge and other university capabilities outside academic environments" (Molas-Gallart et al. 2002). This definition suggests a rather broad understanding of the tasks associated with the third mission. The services provided by the university for the society are at the centre of this view, and are added to the first two missions, teaching and research, as a third object. Thus, it is more about transfer and not interaction. The aim is to activate performances of the university (capabilities) and use them in a broader context (exploitation and use) further on to enable activities, whose roots actually lie in teaching and research (see Fig. 1).

The third mission is the driving force (Mahrl and Pausits 2011) to continue the opening of the universities, to initiate an exchange outside the scientific system, and to find answers to social issues - in Anglo-Saxon university systems it is the common found market-orientation (Altbach and Peterson 2007; Enders et al. 2005; Rothschild and White 1993) — which has still to be worked out by many European higher education systems and universities. The European Union is trying to set some initiatives, such as the Bologna Process, the importance of employability and 'Knowledge Alliances'. Basically, it comes down to scientific, social and economic relations of the university towards society. These include the labour, continuing education, and knowledge markets (Hansen 1999). The Russell Report points out the importance of communication with these markets, and identifies the 
non-academic dissemination of results as a task of the university. This non-academic dissemination includes, for example, reporting on research results in the media. The focus is the exchange with non-academic areas through teaching and research. As the figure shows, there are a variety of activities taking place outside the science systems, which have to also be understood as such. It is important not only to label the tasks for the purpose of better visibility, but also to check their measurability (Mahrl and Pausits 2011).

\subsection{Prime Network}

Some years after the Russell Report, a group of European experts called Prime Network on behalf of the 'Observatory of the European University', worked out another concept of the third mission, accompanied by an evaluation model (radar) to detect and rate activities in this context. They identified eight dimensions and associated indicators (see Fig. 2).

Similar to the Russell Report, the Prime Network also employs it to make the activities more visible and measurable. The model draws on five transverse characteristics as a framework for the activities like autonomy, strategic capabilities, attractiveness, differentiation profile, and territorial embedding. These are relevant for the third mission, because they affect the design options at the institutional level. These transverse characteristics describe the environment and provide the

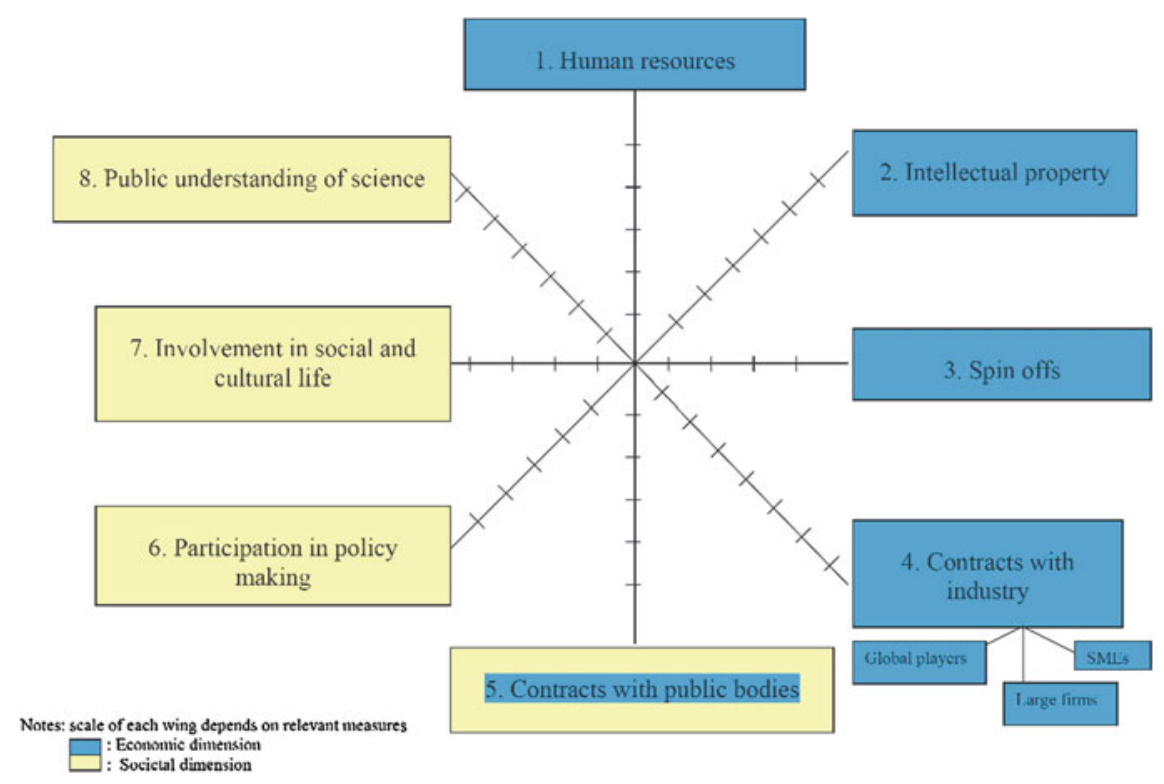

Fig. 2 Functions of the third mission (radar) (PRIME Network 2006) 
framework conditions. The group concludes that the eight functions which can be assigned as the third mission activities are to be subsumed to two main dimensions.

On the one hand, the third mission has an economic dimension, in which resource-oriented economic action patterns can be seen. On the other hand, a social dimension, which can be understood as an increased understanding about science in society. These include, for example, initiatives such as the 'Night of Research' which has been carried out in Austria for years. Another element in the social dimension is the active participation and involvement in social and cultural life. This comprises, among others, the opening of the university libraries for public or participation of the university choir for singers from the region. The last activity that is designated as "commissioned work for the public sector" is attributed to two main dimensions. Although it is socially relevant, it also carries an economic importance, because resulting benefits are financed by the public.

The functions under the economic dimension are mainly the traditional functions of a Technology Transfer Office (TTO) or a Knowledge Management Centre. It is about the exploitation of research and the application of research in the form of innovation. Unfortunately, this innovation is understood in the narrow sense, for example, the field of social innovation is excluded from the concept. However, universities have an important role in the development of social innovation and to support it in the future. Therefore, an extension in understanding of the concept within the Prime Network would be necessary. Otherwise, the third mission is reduced to a conventional TTO, which certainly does not sufficiently satisfy the demands of a modern university and excludes socially relevant issues. Another activity within the economic dimension involves the flow of knowledge from the university to industry. Here, $\mathrm{PhD}$ students and graduates are meant to have had practical experiences outside of the university during their studies. This may be the research that has been conducted on behalf of the business sector, or work carried out jointly with a commercial enterprise or with a representative of a company. However, a research job can be counted under human resources, as well as contact with industry and thus count twice. This example also shows that smooth transitions exist between the different activities and for measurement a clear structure and allocation is required. In this activity, the main goal does not lie in employability, but in penetration of the science system into the non-university sector.

\section{$3.3 \quad E 3 M$}

Another recent European initiative, "European Indicators and Ranking Methodology for University Third Mission" (E3M), has been working on the third mission. Their goals were to initiate an international and an internal institutional discourse on the role of the third mission, and to develop indicators that allow measurability of activities. The third aspect - unlike the previous two conceptswas to develop indicators of rankings. For the third mission activities, hardly any indicators are included in the current ranking systems for higher education. But the 
third mission activities are gradually being seen as an integral part of university functions and activities and thus have to be considered in rankings.

To add more international perspectives and aspects, the group applied the Delphi method and was able to capture opinions of nearly 30 experts in Europe. As a result, three dimensions for the third mission are elaborated: Continuing Education, Technology Transfer and Innovation, and Social Engagement. Each dimension was divided and described in relevant processes, including activities. As a result, there were 18 indicators found in the field of Continuing Education, 16 indicators in the dimension of Technology Transfer and Innovation, and 20 indicators for measuring the Social Engagement.

In contrast to the other two models, one has a variety of possible indicators at hand. A first exemplary test - similar to the Prime Network - shows, however, that many of the developed indicators can only be used in a limited way, since relevant data is either not available, or not available in sufficient quality, or not available in a comparable form (Mahrl and Pausits 2011). Obviously, the data used by universities for monitoring and quality control today covers the area of the third mission only by a little or not at all. Conversely, there are no such factors in the target and performance agreements (e.g. in Austria) and, by contrast, controlling does not foresee detection of these data. Certainly, there is evidence in the context of continuing education, even if only rudimentary or with respect to third-party, and some connection with the work of the TTOs. But, there is little or even no data when it comes to the third dimension, the social engagement.

Perhaps because of this, universities have started to create, similar to business enterprises, self-initiated Social Responsibility Reports (SRR), even just to make this area more visible. Even if a SRR is not congruent with the dimension described by E3M as social engagement, it still shows an increased accountability of universities for their own environment and the region. Although universities are not per se regional development organizations, there are a greater number of universities that recognize the importance of involving the institution in a regional context (Arbo and Benneworth 2007; Lyytinen 2011; OECD 1999).

\section{Differences and Similarities: The Third Mission as a Task}

The different concepts presented indicate a common direction, but require further reflection and extensions. Even if all three concepts have different backgrounds for the conceptual development, they have come to relatively the same results:

- The activities in the third mission are based on the first two missions. Hence, we cannot speak of a third mission as an independent area or a separate task, but more likely as an integrative part of the university, which is very closely linked to teaching and research. 
- To make the third mission visible, it is first necessary to define the dimensions and areas of activity, and clearly name the related indicators. Only so that the third mission can be detected and evaluated as well.

- Institutional transformations and diversification-similar to the concepts presented-are needed. The third mission is a strong system, and context-dependent strategy.

- A university does not need to use all of the dimensions of the third mission, but rather have an active portfolio of activities and ensure their anchoring in the strategy of the university.

- The indicators developed are often descriptive, and are difficult to measure because of missing data in the university. Here, it will be important in the future that universities collect more information about the activities in this context, and use it for the advancement of the institutions.

However, how can the question about whether the third mission exists or not be answered correctly? The third mission has always existed, but it was not seen as an additional task, but rather some initiatives made by single members of the university out of intrinsic motivation. Thus, these activities were not or only rudimentary strategically anchored. Nevertheless, nowadays it is increasingly necessary to strengthen the dialogue between the university and its stakeholders. True to the motto: "Do good and talk about it."

Analogous to the concept of the entrepreneurial university, there is not the "third mission', but rather it is about an institutional anchoring and implementation of activities. Therefore, a variety of deployment paths and examples exist. At the same time, however, it is not sufficient to focus merely on one or the other activity, and to neglect the others completely. Relatively, it is a development of a portfolio of the third mission. The following table shows the differences and similarities of the presented models (Table 1).

All three models show an adequate scientific foundation, although through the different perspectives — national versus international-aiming at complexity reduction. The Russell Report was written for the research-intensive universities as a carrier of the network. This means that the terminology in the national context is clear. Because of the diversity of higher education systems in Europe, however, the

Table 1 Model overview of the third mission

\begin{tabular}{l|l|l|l}
\hline & Russell report & Prime network & E3M \\
\hline Scientific approach & Yes & Yes & Yes \\
\hline Contextualization & No & Yes & No \\
\hline Focus & National & International & International \\
\hline Dimensions & 5 & 8 & 3 \\
\hline Processes & No & No & Yes \\
\hline Activities & Yes & Yes & Yes \\
\hline Indicators & 34 & 21 & 54 \\
\hline Recommendation for actions & Yes & No & Yes \\
\hline
\end{tabular}


other two models have the problem of terminology. For example, the number of students is calculated differently in continuing education; their 'status' and thus the total number are dependent on the particular system of the higher education institution. In some European countries no formal part-time students exist, whereas in other countries this figure represents a separate category for continuing education. Models that have an international focus, therefore, fight with the national system-specific terminologies and conditions.

A particular advantage of the Prime Network model is the use of transverse dimensions. Considering them, it is possible to put universities in a particular context, and to define the third mission alongside the systemic conditions. Institutional integration remains open, since the model is only descriptive. E3M supplies with a "Green Paper" recommendation for policy makers and university administrators, and identifies relevant starting points of implementation. For this purpose, it describes key processes, and not only the activities of the third mission. The Russell Report also provides recommendations that can be used not only for research-intensive universities, but show a high validity for all types of universities.

All three concepts deal in detail with the indicators, and simultaneously show the limits of quantitative methods for the third mission, and the institutional problems of data collection and recording on. Anyway, it is a field that is gaining importance. Because the field of quality development and monitoring in the future will more likely take over the role of the so-called institutional researcher and continue to build analytical activities as support for the university management. This generally means an expansion of the data collection, and analysis and reports on the framework set out by the Ministry towards a strategic decision support. And in particular, the systematic collection and evaluation of data for the third mission.

All models show a portfolio of activities in the third mission that can be provided by a university. So it considers: What can a university do and what role it can offer? But it is also about: what role they should play?-Therefore, it is not about a new revolution, but an evolutionary development, taking account of the limited resources and capacities. At the same time, the university cannot close this development, but must actively participate in the design of the company order.

\section{Third Mission Aspects in Rankings}

In recent years, a number of publications have dealt with rankings and the methodology behind each of these (Federkeil 2004; Hazelkorn 2011; Mahrl and Pausits 2011). Different groups of rankings (such as the reputation-based rankings, the research-based rankings, the teaching-based rankings etc.) use different indicators. Based on the basic assumption and core focus of the rankings, they rely on different indicators, which reflect the basic methodology, as well as perspective of the rankings. Since the first rankings started, there have been a large number of different indicators in use. In fact, rankings are more than a list of indicators, but more a "weighted aggregation of indicators" (Usher and Savino 2007, p. 9). In order to 
look at these indicators, it is necessary to group these indicators into different categories. Based on 26 rankings, Usher and Savino grouped these indicators into eight groups (Usher and Savino 2007): beginning characteristics, learning input (staff), learning input (resources), learning environment, learning output, final outcomes, research and reputation.

While numerous ranking concepts focus on the first and second missions, the third mission is not included as a core element into existing rankings (Mahrl and Pausits 2011). The generally recognised ranking systems - like Academic Ranking of World Universities, commonly known as The Shanghai Ranking, or The Times Higher Education World University Ranking - present indicators to assess excellence at universities mainly by research and teaching. While rankings can improve quality assurance by allowing the institutions to understand their own performance, develop best practices and provide effective and efficient value to society, it is important that the third mission activities - as components of the institutional performance - are also part of such rankings. Furthermore, Usher and Medow group existing indicators mainly dedicated to the first and second mission. However, there are no commonly agreed indicators or methodologies to assess quality in the third mission activities. The above mentioned initiatives (Russell Group, Prime Network, E3M) identify a set of indicators, which can be used to improve rankings and to integrate additional aspects of university activities and outputs. The following table shows such indicators to measure the third mission activities (Table 2). ${ }^{5}$

The third mission as one of the driving forces for HE development should receive more attention in rankings. The EUA second report (EUA 2013) on rankings highlights that there is a significant improvement on rankings. The report talks mainly about research and teaching and does not pay attention to additional quality elements of HEIs. Moreover, the focus of a discussion about rankings is methodology, weights and data. Existing rankings have clear focal points. In general, while global rankings have research in focus, regional and national rankings look at teaching.

Based on the introduced third mission frameworks and set of indicators, Table 3 shows the different focus of the rankings and the missing perspective on the third mission. In this table, third mission indicators are counted as indicators identified in the frameworks of E3M, The Russell Report or Prime Networks. The division between teaching/learning and research is based on the groups given by the dimensions of the rankings and group of indicators in the dimensions of the methodology descriptions elaborated and aggregated by Usher and Medow (2009, p. 10f).

All 11 rankings represent different groups of rankings like global ranking or national ranking; rankings with focus on research or teaching; and also different parts of the world. The last ranking is dedicated to measure entire HE systems and, therefore, slightly different in methodology and focus from the other rankings. But

\footnotetext{
${ }^{5}$ See the final report of the OEU project, go to www.enid-europe.org or www.prime-noe.org.
} 
Table 2 The "radar" of the third mission elements proposed by The PRIME project (see www. prime-noe.org)

\begin{tabular}{|c|c|}
\hline Issues & Focus, main indicators and descriptors \\
\hline 1. Human resources & $\begin{array}{l}\text { Focus: transfer of embodied knowledge in } \mathrm{PhD} \text { students and } \\
\text { graduates } \\
\text { Comment: this axis screens the transfer of "competences } \\
\text { trained through research" to industry and "mission oriented" } \\
\text { public services Indicators: the number and share of PhD } \\
\text { diploma going to industry and public services (distinguishing } \\
\text { between R\&D and non R\&D positions) }\end{array}$ \\
\hline 2. Intellectual property & $\begin{array}{l}\text { Focus: codified knowledge produced by the university and its } \\
\text { management (patents, copyright) } \\
\text { Indicators concern not only patents owned by the university, } \\
\text { but university "inventors" (whatever the grantee is). Patent } \\
\text { numbers should be complemented by licences granted and fees } \\
\text { received }\end{array}$ \\
\hline 3. Spin offs & $\begin{array}{l}\text { Focus: knowledge transfer through entrepreneurship } \\
\text { Indicators: simple counts are not enough, a typology of } \\
\text { relationship between spin-off firms and labs has to be } \\
\text { considered (staff that left, staff still involved, research contracts, } \\
\text { licences granted...) } \\
\text { Descriptors are needed to characterise university involvement } \\
\text { and support: dedicated teams, incubator, funds provided (in } \\
\text { whatever form, including shareholding) }\end{array}$ \\
\hline 4. Contracts with industry & $\begin{array}{l}\text { Focus: knowledge co-production and circulation to industry. } \\
\text { This is taken as the main marker of the attractiveness of } \\
\text { universities for existing economic actors } \\
\text { Indicators: number of contracts, amount as a share of total } \\
\text { resources, type of partners (global, large firms, SME) are the } \\
\text { key aspects. Level of concentration (sectorial and/or on a few } \\
\text { partners), types of contract (research, consultancy, services) } \\
\text { and duration are important complementary aspects } \\
\text { Delineating in large labs the degree of concentration (thematic } \\
\text { or on given teams) is also often of strategic interest } \\
\text { Comment: this is often complemented by a "soft" dimension } \\
\text { where account is taken of membership in professional } \\
\text { associations (and role played in given professional networks), } \\
\text { professional publications, activities in continuous training, } \\
\text { consultancy activities (often not paid to the lab) and internships } \\
\text { (master students accepted in "stages") } \\
\text { Focus: the "public service" dimension of research activities }\end{array}$ \\
\hline $\begin{array}{l}\text { 5. Contracts with public } \\
\text { bodies }\end{array}$ & $\begin{array}{l}\text { Indicators: similar aspects, as for contract with industry, apply, } \\
\text { especially differentiating between co-research and services } \\
\text { Comment: it is important to complement contracts by } \\
\text { non-market relations which are often critical when labs focus } \\
\text { on social and cultural dimensions (this has often important } \\
\text { implications for identity building, but also for economic } \\
\text { activities such as tourism). This is also very present in health } \\
\text { research (with clinical trials for new therapeutic protocols...) }\end{array}$ \\
\hline
\end{tabular}


Table 2 (continued)

\begin{tabular}{|c|c|}
\hline Issues & Focus, main indicators and descriptors \\
\hline $\begin{array}{l}\text { 6. Participation into policy } \\
\text { making }\end{array}$ & $\begin{array}{l}\text { Focus: involvement in the shaping and/or implementation of } \\
\text { policies (at different levels). This is often captured under the } \\
\text { wording of "expertise", including policy studies, participation } \\
\text { in the formulation of long-term programmes or to 'formalised' } \\
\text { debates on S\&T\&I policy, involvement into standard setting } \\
\text { committees, into committees and work on safety rules } \\
\text { Descriptors: the usual mode is to consider a description in the } \\
\text { annual report in order to build an indicator of presence and } \\
\text { 'relative importance' (number of different activities and } \\
\text { entities, number of persons involved) }\end{array}$ \\
\hline $\begin{array}{l}\text { 7. Involvement into social } \\
\text { and cultural life }\end{array}$ & $\begin{array}{l}\text { Focus: involvement of the university in "societal" (mostly } \\
\text { "city") life } \\
\text { Comments: } \\
\text { - A number of universities have lasting "facilities" that } \\
\text { participate to the social and cultural life of the city (museums, } \\
\text { orchestra, sport facilities, facilities like libraries open to schools } \\
\text { or citizens...). Some involve themselves opening "social } \\
\text { services" (like law shops) } \\
\text { - Besides these "structural" investments, a number of labs } \\
\text { involve themselves in given social and cultural events (expos, } \\
\text { concerts, urban development projects...) } \\
\text { Descriptors: there is little accumulated knowledge on how to } \\
\text { account for such activities. Two approaches are being } \\
\text { experimented: accounting for relative importance in all } \\
\text { university investments and/or activities, positioning these } \\
\text { within their own environment (as can be done for museums) }\end{array}$ \\
\hline $\begin{array}{l}\text { 8. Public understanding of } \\
\text { science }\end{array}$ & $\begin{array}{l}\text { Focus: interaction with society } \\
\text { Comment: the choice has been to focus here only on } \\
\text { "dissemination" and interaction with the "general public". All } \\
\text { growing aspects upon involvement into public debates are } \\
\text { considered to be part of dimension } 6 \text { (participation to policy } \\
\text { making) } \\
\text { Descriptors: follow sets of activities deployed (open days, } \\
\text { involvement in scientific fairs and the like, involvement into } \\
\text { general press and science journals for the public, involvement } \\
\text { in the different media, construction of "dissemination" and } \\
\text { "interactive" websites, involvement into activities directed } \\
\text { towards children and secondary schools...). Differentiate } \\
\text { between individual initiatives and proactive policies of labs and } \\
\text { of the university (as a whole or through its departments) }\end{array}$ \\
\hline
\end{tabular}

also, here, the third mission plays a rather limited role. However, compared to the other "traditional" institutional rankings, the third mission got higher attention. Only two out of 10 rankings with league tables use indicators related to third mission. While at the system level (U21 Rankings), it seems that the third mission is a more relevant element.

If we look to other rankings without league tables like $\mathrm{CHE}$, we find the same picture. $86 \%$ of the CHE Ranking indicators are related to teaching and learning 
Table 3 Indicator division of university missions in rankings (\%)

\begin{tabular}{|c|c|c|c|}
\hline & Teaching/learning & Research & $\begin{array}{l}\text { Third } \\
\text { mission }\end{array}$ \\
\hline Shanghai Jiao Tong University Word Ranking & 10 & 90 & 0 \\
\hline $\begin{array}{l}\text { Times Higher Education World University } \\
\text { Rankings }\end{array}$ & 33.75 & 59.50 & 6.75 \\
\hline US News and World Report & 98 & 2 & 0 \\
\hline QS World University Ranking & 80 & 20 & 0 \\
\hline The Academic Ranking of World Universities & 10 & 90 & 0 \\
\hline National Taiwan University Ranking & 0 & 100 & 0 \\
\hline University Ranking by Academic Performance & 0 & 100 & 0 \\
\hline Perspektywy & 75 & 16 & 9 \\
\hline \multicolumn{4}{|l|}{ Maclean's University Rankings } \\
\hline La Republica & 80 & 20 & \\
\hline $\begin{array}{l}\text { U21 Rankings of National Higher Education } \\
\text { Systems }\end{array}$ & 38.30 & 48.5 & 13.65 \\
\hline
\end{tabular}

and $14 \%$ to research. In the case of U-Multirank, there is a significant change in the dimensions of the ranking, and with this, the focus of the ranking (institutional part). U-Multirank - which has presented the first results in 2014 - identifies five dimensions: teaching and learning, research, knowledge transfer, international orientation and regional engagement. If we take a closer look and aggregate the different indicators into the three missions, we see the following result: $22 \%$ is dedicated to teaching and learning, $37 \%$ is related to research, and finally $41 \%$ is associated to third mission. U-Multirank is the first global ranking with a different perspective, introducing new indicators related to third mission.

\section{Summary and Outlook}

The greater competitiveness, the changing governance structures and financing framework are forcing the universities to a greater profile and differentiation. In addition to teaching and research, this can be done also through the third mission. This is not a question of faith, but a necessity of a modern university, as market and service orientation of universities can and will be even more intense over this area in the future.

A basic discussion of the topic, the third mission, is currently missing in many Bologna countries. Here, it is much more appealing to the autonomy of the universities and anchored this social responsibility rudimentary into the target and performance agreements. If the individual strategies of universities are put under the microscope, it is seen that, as an anchor, it is only in certain segments of the third 
mission. This can, of course, mean taking a (partial) success. Probably for this reason, it would require recognition by policy making bodies, as well as more attention and more attention within the Bologna Process as well. The third mission is not a redefinition of the university. At the end, the third mission is a vehicle of further diversification and profile building.

However, getting there requires more consideration on the system, institutional, and individual level. It requires both a top-down and a bottom-up approach. Already what is happening at the universities is much of what the university does not know, because it is not recorded or documented. Often there are initiatives of university members who are active through an inner drive out. Here, it is necessary to further protect these forces and to motivate others, without it becoming a compulsion. Finally, there is an organic and cultural development that allows this area to be understood as an integral part of the duties of a university to design and use.

Open Access This chapter is distributed under the terms of the Creative Commons Attribution Noncommercial License, which permits any noncommercial use, distribution, and reproduction in any medium, provided the original author(s) and source are credited.

\section{References}

Altbach, P. G., \& Peterson, P. M. (2007). Higher education in the new century. Global challenges and innovative ideas. Rotterdam: Sense Publishers.

Arbo, P., \& Benneworth, P. (2007). Understanding the regional contribution of higher education institutions: A literature review. Paris: OECD.

Barnett, R. (2003). Beyond all reason: Living with ideology in the university. Buckingham: UK Society for Research into Higher Education, Open University Press.

Bergan, L. P., Egron-Polak, E., Kohler, J., \& Purser, L. (2011). Leadership and governance in higher education. Handbook for decision-makers and administrators. Berlin: Raabe Academic Publishers.

Brennan, J., \& Shah, T. (2000). Managing quality in higher education. An international perspective on institutional assessment and change. Buckingham, UK: OECD/SRHE/Open University Press.

Clark, B. (1983). The higher education system: Academic organisation in crossnational perspective. Berkeley: University of California Press.

Clark, B. R. (1998). Creating entrepreneurial universities: Organisational pathways to transformation. Oxford, New York, Tokyo: IAU Press/Pergamon.

Clark, B. R. (2004). Sustaining change in universities: Continuities in case studies and concepts. Maidenhead, England \& New York: Society for Research into Higher Education, Open University Press.

Cross, E., \& Pickering, H. (2008). The contribution of higher education to regional cultural development in the North East of England.

D'Ambrosio, M., \& Ehrenberg, R. G. (2007). Transformational change in higher education. Positioning colleges and universities for future success. Cheltenham, UK; Northampton, MA: Edward Elgar.

Davies, P., Németh, B., \& Pausits, A. (2010). Development and management of university lifelong learning. In J. Huisman \& A. Pausits (Eds.), Higher Education management and development. Waxmann: Münster. 
Daxner, M. (2010). Higher education and society. In J. Huisman \& A. Pausits (Eds.), Education management and development. Waxmann: Münster.

Deutscher, B. (1975). Umrisse und Perspektiven der Weiterbildung Stuttgart: Klett.

Edquist, C. (1997). Systems of innovation: Technologies, institutions, and organizations. London: Pinter.

Enders, J., File, J., Huisman, J., \& Westerheiden, D. F. (2005). The European higher education and research landscape 2020: Scenarios and strategic debates. Enschede: Center for Higher Education and Policy Studies (CHEPS).

Etzkowitz, H. (2008). The triple helix. University-industry-government innovation in action. New York: Routledge.

Etzkowitz, H., \& Leydesdorff, L. (1997). Universities and the global knowledge economy. A triple helix of university-industry-government relations. New York; London: Pinter.

Etzkowitz, H., \& Leydesdorff, L. (2000). The dynamics of innovation: From national systems and mode 2 to a triple helix of university-industry-government relations. Research Policy, 29(29), 109.

EUA. (2013). Global university rankings and their impact: Report II. European University Association. Retrieved from http://www.eua.be/university-autonomy-in-europe

Federkeil, G. (2004). Benchmarking und Ranking als Instrumente des Leistungsvergleichs. In W. Fröhlich \& W. Jütte (Eds.), Qualitätsentwicklung in der postgradualen Weiterbildung. Waxmann: Münster.

Gibbons, M., Limoges, C., Nowotny, H., Schwartzman, S., Scott, P., \& Trow, M. (1994). The new production of knowledge: The dynamics of science and research in contemporary societies. London: Sage Publications.

Goddard, J., \& Puukka, J. (2008). The engagement of higher education institutions in regional development: An overview of the opportunities and challenges. Higher Education Management and Policy.

Hansen, U. (1999). Die Universität als Dienstleister: Thesen für ein leistungsfähigeres Management von Hochschulen. In B. Stauss, I. Balderjahn, \& F. Wimmer (Eds.), Dientsleistungsorientierung in der universitären Ausbildung: Mehr Qualität im betriebswirtschaftlichen Studium. Stuttgart: Schöffer-Poeschel Verlag.

Hazelkorn, E. (2011). Rankings and the reshaping of higher education: The battle for world-class excellence. London: Palgrave Macmillan.

Huisman, J., \& Pausits, A. (2010). Higher education management and development. Münster: Waxmann.

Kerr, C. (2001). The uses of the university (Vol. 5). Cambridge, MA: Harvard University Press.

Lyytinen, A. (2011). Finnish polytechnics in the regional innovation system. Towards new ways of action.

Maassen, P. A. M., \& Olsen, J. P. (2007). University dynamics and European integration. Dordrecht: Springer.

Mahrl, M., \& Pausits, A. (2011). Third mission indicators for new ranking methodologies. Evaluation in Higher Education, 4(1).

Molas-Gallart, J., Salter, A., Patel, P., Scott, A., \& Duran, X. (2002). Measuring third stream activities. Final report to the Russel Group of universities. Brighton: SPRU, University of Sussex.

Montesinos, P., Carot, J. M., Martinez, J. M., \& Mora, F. (2008). Third mission ranking for world class universities: Beyond teaching and research. Higher Education in Europe, 33(2), 259-271.

Nygaard, C., \& Holtham, C. (2008). Understanding learning-centred higher education. Copenhagen: Copenhagen Business School Press; Distribution, North America, International Specialized Book Services, Portland, OR.

OECD. (1999). The response of higher education institutions to regional need.

Pichl, E. (2012). Universitäre Profilbildung im Kontext des österreichsichen Hochschulraums und des Universitätsgesetzes 2002. Zeitschrift für Hochschulrecht, Hochschulmanagement und Hochschulpolitik: zfhr.

PRIME Network. (2006). Observatory of the European University Methodological Guide. 
Rothschild, M., \& White, L. (1993). The university in the marketplace: Some insights and some puzzles. In C. Clotfelter \& M. Rothschild (Eds.), Studies of supply and demand in higher education. Chicago: The University of Chicago Press.

Shattock, M. (2003). Managing successful universities. Berkshire: Society for Research into Higher Education, Open University Press.

Usher, A., \& Medow, J. (2009). A global survey of university rankings and league tables. In B. Kehm \& B. Stensaker (Eds.), University rankings, diversity, and the new landscape of higher education. Global perspectives on higher education. Rotterdam/Boston: Sense Publishers.

Usher, A., \& Savino, M. (2007). A global survey of university ranking and league tables. Higher Education in Europe, 5(15).

van Vught, F. A. (2009). Mapping the higher education landscape towards a European classification of higher education. Dordrecht: Springer.

Weick, K. E. (1976). Educational organization as loosely coupled systems. Administrative Science Quarterly, 21(1), 1-19. 